\title{
Online Marketing: Problems and Prospects as Perceived by Customers
}

\author{
G. Latha, B. Karthikeyan, V. Sitharthasankar
}

\begin{abstract}
Changes are taking place in all fields at an accelerated rate. Anyone who is accepting these changes and adopting them are benefitting out of these changes. There are people who could not take up these changes and they follow the steps that have been followed traditionally. In the case of marketing, there are two main categories namely offline marketing and online marketing. Offline marketing involves marketing of goods and services which doesn't involve the use of internet. On the other hand, online marketing involves the use of internet for marketing of goods and services to customers. The emergence of computers and internet has made dramatic changes in all fields especially in marketing and advertising. The wide use of smart phones and internet access in these phones help companies reach customers easily. On the other side, customers access the products and services necessary for them at their finger tips. Online marketing has reached customers in the nook and corner of the country. It would be interesting to study the perception of customers towards online marketing. This paper analyses the problems and prospects of online marketing as perceived by the customers. Majority of the respondents utilize and opine that online marketing is beneficial to them in many ways. But they also record some of the hardships faced by them in online marketing. Upgrading of services provided by online marketing and minimizing the challenges faced by it will help to develop online marketing to greater heights.
\end{abstract}

Keywords: Online Marketing, Problems, Prospects, Customer Perception.

\section{INTRODUCTION}

Marketing refers to all the activities which a company undertakes to promote the buying and selling of products and services. Its main objective is to match the needs and wants of customers or potential customers with the products and services offered by them.

Revised Manuscript Received on July 22, 2019.

Dr. G. Latha, Associate Professor, Dept of Business Administration, Annamalai University, Annamalainagar, Tamilnaud, India, email: g_latha2002@yahoo.co.in

Dr. B. Karthikeyan, Associate Professor, Dept of Business Administration, Annamalai University, Annamalainagar, Tamilnaud, India, email:bkn_au@yahoo.com

Dr. V. Sithartha Sankar, Assistant Professor, Dept of Business Administration, Annamalai University, Annamalainagar, Tamilnaud, India, email: varshansidhu@gmail.com
Marketing has been carried out traditionally through many ways through print media, word of mouth, mail, telemarketing etc. There are two main categories of marketing namely offline marketing and online marketing. Offline marketing involves marketing of goods and services which doesn't involve the use of internet.

On the other hand, online marketing involves the use of internet for marketing of goods and services to customers. With the advent of internet and its wide usage, online marketing has become popular. The emergence of computers and internet has made dramatic changes in all fields especially in marketing and advertising. The wide use of smart phones and internet access even in phones help companies reach customers easily. On the other side, customers access the products and services necessary for them at their finger tips. Customers can view the wide range of products and services offered by a company, latest models introduced, comparison of features and price of the same category product, offers if any, mode of payment an delivery etc.

a. There are Seven Major Categories of Online Marketing Namely

- Search Engine Optimization

- Search Engine Marketing

- Pay-Per-Click Advertising

- Content Marketing

- Social Media Marketing

- Affiliate Marketing

- Email Marketing

b. Online Marketing has the Following Advantages:

- Time saving as customers can have a glance of the products and analyse its features without physically going to the market.

- Cost effective as companies need not spend on advertising

- Convenient because customers check and purchase products at their convenient time, and make purchase decisions 24X7

- Competitive advantage can be gained by the company offering such online services

- Targeting of customers becomes easy

c. Online marketing has its own disadvantages

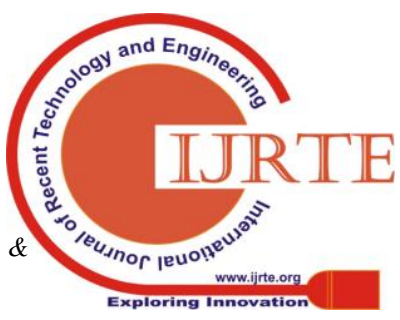


- Lack of tangibility of the product

- Lack of option to touch and feel the product

- Lack of option to have a trial

\section{OBJECTIVE}

The main objective of the paper is to identify customer perception towards the problems and prospects of online marketing.

\section{METHODOLOGY}

Primary data and secondary data are the source of information for this paper. Primary data were collected through a questionnaire designed for the study. The questionnaires were circulated to respondents who benefit through online marketing. Sample size for the study is 100.Convenience sampling has been followed to identify the problems and prospects of online marketing perceived by customers using it.

\section{RESULT AND DISCUSSION}

Table 1 shows the profile of the respondents.

\begin{tabular}{|c|c|c|c|}
\hline \multirow{2}{*}{ Gender } & Male & Female & \\
\cline { 2 - 4 } & 60 & 40 & \\
\hline \multirow{2}{*}{ Age } & $<30$ years & $30-50$ years & $>50$ years \\
\cline { 2 - 4 } Income & 20 & 50 & 30 \\
\hline \multirow{3}{*}{$\begin{array}{c}\text { Working } \\
\text { Status }\end{array}$} & $<$ Rs.40,000 & $\begin{array}{c}\text { Rs.40,000- } \\
60,000\end{array}$ & $>$ Rs.60,000 \\
\cline { 2 - 4 } & 10 & 40 & 50 \\
\hline
\end{tabular}

It can be inferred from table 1 that $60 \%$ of the respondents are male and $40 \%$ are female. $20 \%$ of them are in the age group of less than 30 years. $50 \%$ of them are in 31 to 50 years category and $30 \%$ of them in more than 50 years of age category. $10 \%$ of the respondents have an income of less than 40,000 rupees. $40 \%$ of them have an income between 40,000 and 60,000 rupees. $50 \%$ of them have an income of more than 60,000 rupees.

Table 2 shows the utilization of online marketing services by customers.

\begin{tabular}{|c|c|c|}
\hline Type of product / Service & Yes & No \\
\hline $\begin{array}{c}\text { Clothes (Sarees, dress materials, } \\
\text { readymade garments, Mens wear) }\end{array}$ & $90 \%$ & $10 \%$ \\
\hline Accessories (Jewels, watch, & $70 \%$ & $30 \%$ \\
\hline Footwear (Shoes, casual wears) & $80 \%$ & $20 \%$ \\
\hline Services (Insurance, parcel) & $80 \%$ & $20 \%$ \\
\hline Mobile phones, laptops \& gadgets & $40 \%$ & $60 \%$ \\
\hline Books & $60 \%$ & $40 \%$ \\
\hline Furniture & $40 \%$ & $60 \%$ \\
\hline
\end{tabular}

It can be inferred from the Table 2 that majority of the respondents use online marketing services for purchasing clothes, accessories, footwear, services and books. Majority of the respondents do not prefer online for mobile phones and furniture as they want to physically check and verify the quality.

Table 3 shows the customer perception towards the advantages of online marketing

\begin{tabular}{|c|c|}
\hline Advantage & Yes \\
\hline Time saving & $100 \%$ \\
\hline Cost effective & $100 \%$ \\
\hline Convenience & $100 \%$ \\
\hline Comparison of products & $100 \%$ \\
\hline $24 X 7$ access & $100 \%$ \\
\hline
\end{tabular}

It can be inferred from the table 3 that all the respondents perceive online marketing services as time saving, cost effective, convenient, suitable for comparing products and comfortable anytime anywhere access.

Table 4 shows the customer perception towards the drawbacks of online marketing

\begin{tabular}{|c|c|c|}
\hline Drawback & Yes & No \\
\hline Genuineness of the service & $80 \%$ & $20 \%$ \\
\hline Seeing \& feeling the product & $90 \%$ & $10 \%$ \\
\hline Trial Options & $90 \%$ & $10 \%$ \\
\hline Exchange of damaged products & $75 \%$ & $25 \%$ \\
\hline $\begin{array}{c}\text { Getting refund for damaged } \\
\text { products }\end{array}$ & $80 \%$ & $20 \%$ \\
\hline
\end{tabular}

Table 4 shows that majority of the customers perceive certain drawbacks like lack of genuineness, physical verification of the products, trial options and managing with damaged products.

\section{RECOMMENDATIONS}

Customers have easy access to various products and services through online marketing. Since they perceive many advantages, online marketing services can be extended to various products and services. Customers also perceive certain drawbacks, which when eliminated or minimized help companies gain competitive advantage over their competitors.

\section{CONCLUSION}

Changes are taking place in all fields at an accelerated rate. Anyone who is accepting these changes and adopting them are benefitting out of these changes. The emergence of computers and internet and wide use of smart phones and internet access in these phones has made dramatic changes in all fields especially in marketing and advertising which further help companies reach customers easily. Expansion of online marketing to various products and services help companies to tap potential customers. 


\section{REFERENCE}

1. https://en.wikipedia.org/wiki/Digital_marketing

2. https://webstrategies.com/digital-marketing-7-differe nt-types/

3. https://www.optimizely.com/optimization-glossary/o nline-marketing/

\section{FIRST AUTHOR PROFILE}

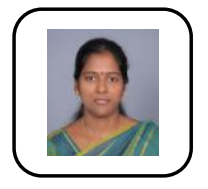

Dr. G. Latha is working as Associate Professor in the Department of Business Administration, Annamalai University, Chidambaram. She has completed her B.E (EEE), M.B.A., Ph.D., from Annamalai University. She has 16 years of research experience and her area of interest includes Human Resource management, Stress Management and Entrepreneurship. She has published nearly twenty articles in National and International Journals and also presented 15 paper in National and International Conferences. She is acting as the Associate Editor in the Annamalai International Journal of Business Studies and Research (AIJBSR).

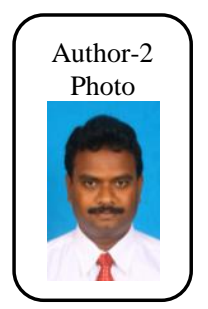

\section{SECOND AUTHOR PROFILE}

Dr. B. Karthikeyan is working as Associate Professor in Dept. of Business Administration, Annamalai University since year 2003, Chidambaram. Completed his graduate in M.B.A.,M.Phil., Ph.D., at Annamalai university, He has 16 years of research experience and her area of interest includes Human Resource management, and Marketing. He has published nearly twenty articles in National and International Journals and also presented 15 paper in National and International Conferences. He is acting as the Editor in the International Journal of Management Focus(IJMF).

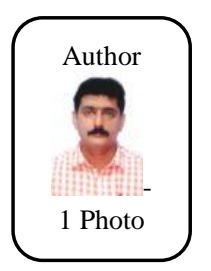

\section{THIRD AUTHOR PROFILE}

Dr. V. Sithartha sankar is currently working as a Assistant Professor at Annamalai University Since year 2004, Chidambaram. Completed his graduate in Business administration at Annamalai university, Chidambram and Ph.D., in Business administration at Annamalai university, Chidambram. Research area of interest Human Resource management, Stress Management, Published ten articles in National and International Journals and also presented 8 paper in National and International Conferences. Two years of research experience. 